\title{
The Implementation of Multicultural Values in the Interaction of Transmigration Communities Through "Malakok" in Nagari Sungai Sirah Silaut
}

\author{
Isnarmi Moeis ${ }^{1, *}$, Junaidi Indrawadi ${ }^{2}$, Cici Nur Azizah $^{3}$, Roni Priyoga Putra ${ }^{4}$ \\ 1,2,3,4 Universitas Negeri Padang, Padang, Indonesia \\ *Corresponding author.Email: isnarmi213@fis.unp.ac.id
}

\begin{abstract}
Minangkabau, is one of the largest ethnic groups in Indonesia that has uniqueness in the context of a multicultural society. In this ethnic, there is a tradition that unites immigrants and indigenous tribes by entering migrants into one of the existing tribes, called Malakok. The life of the immigrant community with the natives through Malakok runs in harmony. In the other hand, multicultural values have been built such as mutual respect between different ethnicities and religions, equality and brotherhood among others in everyday life. This study aims to analyze these multicultural values and the factors behind the formation of these values. The research was conducted using a phenomenological approach. Data were collected using observation techniques, in-depth interviews and Focus Group Discussions at the research site. The results of the study show that the people of the two tribes live in brotherhood, respect each other, are fair to each other, and each tribe still maintains its identity.
\end{abstract}

Keywords: Malakok, Multicultural Values, Social Integration.

\section{INTRODUCTION}

Minangkabau is an ethnic group that is open to other cultures. The Minangkabau people always provide opportunities for immigrants to unite with the indigenous people ([1] One of them is to unite different tribes through malakok ([2]. Malakok in Indonesian means the attachment of one tribe to another. This tradition is a multicultural concept based on local wisdom. Malakok has implications for peace, and ease of conflict resolution for the people of the two different groups ([3]. The malakok tradition is a reflection of the openness of the Minangkabau community to accept immigrants from different ethnicities and religions.

A lot of researches show the uniqueness of the culture malakok in various areas in West Sumatra. For the Minangkabau as the melayu community, malakok is a sign that the migrant communities became a part of citizens in the new place [4]. This tradition can be said as a model of negotiation people of different tribes, and even different religions ([5], [6]. Along with the history of the indigenous people of Minangkabau, the tradition malakok can be regarded as evidence of the shift in the social life of monocultures to multicultural for the Minangkabau ethnic ([7]. Analogically, can be said malakok is the entrance of the merging of migrants into a new life with native Minangkabau [8]. The results of the study showed that malakok is an instrument guard harmonization in many diverse communities.

In the previous study, has not been a lot of talk about the tradition of malakok that is associated with the values of the multicultural living in the society interaction. These studies fill the shortage of previous studies by looking at the form-the form of the value of multicultural and factor the background of the strengthening of the value. This study took place in Sungai Sirah, Silaut District, West Sumatera, Indonesia. 


\section{THEORETICAL REVIEW}

Implementation of multicultural in social life can be seen in the interactions between members of the society. The value includes the value of humanity, openness, tolerance, have moral [9], [10]. Community multiculturalists have high empathy to the existence of the other person who is got discriminated [11], [12]. According to that, it is affirmed that the value of multicultural is inherent value in the form of attitudes accepting of other people without distinction based on religion, ethnicity, race [13]. The value of multicultural can be realized also associated with intelligence, the emotional intelligence, self-confidence, and creativity of the person [14]-[16]. In a society that upholds the values of multicultural free from fear because everyone appreciates a different person [17]. The value of multicultural attached a difference in a diverse society.

Tradition of malakok in Minangkabau, can be viewed as a process of social integration. Social integration not only the process of learning through enculturation and acculturation, but the process of remembering (memory) features recorded in the community culture ([18].. The dynamic of the process leads both of groups adapt the ways that suitable in the interaction (van Krieken, 2012)). In addition, the equality takes place in the process that rising the awareness of togetherness between race, ethnicity and culture ([19].). In natural communities, groups formulate the shared values such as awareness of identity, accepting differences, and the sensitivity of culture and equality (Noe et al., 2018)). In the end, be recognized by all groups, that the differences can be bridged with human values [20]. Similarly, the tradition of malakok in the tradition of the Minangkabau has become adhesive ethnic, and different religions into one unified society (Indraddin et al., 2019;). In life together through malakok, all people stick to the principle that identity is not to be opposed to each other but are viewed as a common resource.

\section{METHODS}

This research uses qualitative research method with a phenomenological approach [23] In this Study, the researcher will explore and look deeply about the value of multicultural in local wisdom malakok in Sungai Sirah. Data collection techniques were done in three ways, namely through a series of field observation, interview and FGD. The results of the study were analyzed qualitatively by following the process of data collection, verification, coding, reduction, display, and interpretation. The research informants were determined purposively, in this case wali nagari and their subordinates, traditional leaders, religious leaders (theologian), intellectual and community of malakok.

\section{RESULTS AND DISCUSSION}

In this study there are two concepts that became the focus of analysis. Firstly, malakok is a local wisdom with the values in it. Second, the values of multicultural applied by the society in their interactions. Those values are related to the power of identity, the ability to think openly, and desire to apply fair (Moeis , 2014;). The manifestation of the third values will run intrinsically in the interaction as mutual respect, can accept the differences, and tolerance ([26]-[28]. In fact, multicultural values were created through a wide variety of cultural phenomena that occur in tradition or custom (Handoyo et.al 2015). One of these traditions is malakok, in migrant communities in Sungai Sirah, District Silaut Sumatera Barat.

The early arrival of transmigration to the Silaut area was initiated by Masri from Minangkabau ethnic. He is a community leader or ninik mamak. He revealed that the country to build community needs and life together. Therefore, he bought a spacious bush land in Sungai Sirah, Then the land was in a plot for farming, and for shelter of voluntarily immigrants, who came later on. The presence of first immigrants along with government programs that encourage immigrants from java island to other island in Indonesia. They were supported by the cost of housing. Afterall, the region Silaut began to develop, with the arrival of people rom different ethnic and religious in Lampung, Medan, and other areas in the West Sumatra. They lives side by side in harmony. (FGD 10 September 2020)

The unity and integration of the community is reinforced with malakok, carried out by migrant communities. Malakok is defined in the regulations of the local customs, and expressed in the proverbial custom "Nagari bapaga undang, kampuang bapaga buek, tiok lasuang ba ayam gadang, salah tampuah buliah diambok" (Meaning that each region and community has its own rules, and everyone who comes must comply with voluntary). On the basis of the customary rules is defined procedure malakok that must be endured by migrant communities. With a note, that malakok not coercion but voluntarism.

The procedures of Malakok firstly: maninjau datuak (finding leaders). This is carried out after setting the tribe which will be used as a place malakok. The newcomers should contact the chief (datuak) of the tribe. Then, the chief take care of him, and teach the materials related to the Minangkabau culture as new customs for the newcomers. The second "maisi carano", meaning the newcomer is required to pay an amount of money, Money is put as the deposit of the tribe, then used in social affairs like meeting of member tribe. Activities malakok done without coercion. Indigenous leaders and 
community leaders just persuade whenever the immigrants do malakok, then they will be part of the Minangkabau ethnic. The consequences of malakok, they have rights and obligations equal to the one of indigenous member. They will be accommodated at a every custom activity. The basic principle of malakok is Volunteerism. Malakok can be done individually, (the head of the family) or group (several families).

The combination of acceptance of tribal leaders with voluntary immigrants to carry out malakok, became the basis of strengthening the value of self-identity. All the people who came to the land of the Minangkabau, will be the brothers, without losing their original identity. All member will be treated fairly, and will be part of the tribe community activities. Interestingly, though migrant communities have a new tribe as the Minangkabau, they do not lose the identity and characteristics indigenous tribes. "Malakok is a recognition that the equivalent in the life of society, and become part of the Minangkabau, but they can still continue the tradition and customs of the native tribes of them" (FGD, 10 September 2020).

The willingness of migrants carries out the procession of the malakok show openness in thinking and acting. On the one hand, the majority of communities receive even desire the arrival of the new society to lie within them. On the other handpeople entrants agree with the voluntary a process to be a part of the Minangkabau. Newcomers to feel the benefits of being part of the Minangkabau, as well as remove sense of alienation as newcomers. The openness of thinking was in line with the volunteerism of reciprocity by a newcomer and also a native to be together in their tribe. This reality shows wisdom of the cultural emphasis on brotherhood in over the identity of the tribe. The synthesis between openness, volunteerism and the brotherhood show the implementation of multicultural in the life of the society of cross-cultural and ethnic.

The tradition of Malakok has social, economic and psychological implications. In line with the dynamics of society, there is a strengthening of multicultural values such as openness, identity, equality and acceptance. These values give a sense of security to the community both immigrants and natives. Further, it accelerates economic growth community of immigrants and indigenous people. This is the goal of the transmigration program [29]. In sum, malakok is an advanced solution to the problem of population in Indonesia [30].

The tradition of malakok enrichs the multicultural society in Indonesia. The principle of multiculturalism is the recognition of cultural diversity and equality ([31], [32]. In turn, it came the identity of the ethno different cultures [33]. Multiculturalism means that the society emphasizes identity, prioritizes openness, and respects the values held by its community[15]. malakok can be a model of a multicultural society in the repertoire of the nation. It accommodates three values of the adhesive differences, such as recognition of the differences, the unity of the community or the nation, and equality [34]). Therefore, This multicultural society needs to be maintained and managed properly [35].

\section{CONCLUSION}

Implementation of multicultural in the tradition of malakok starting from volunteerism, and openness between groups to unite. The dynamics of the integration within malakok implying values of multicultural such as the acceptance of diversity, fair treatment of all groups. The value of multicultural in the tradition of malakok confirmed that differences between groups can be united with a sense of togetherness and brotherhood. In short, the tradition of malakok enriches the repertoire of Indonesia as a multicultural state.

\section{AUTHORS' CONTRIBUTIONS}

Isnarmi Moeis, collecting and analyzing data, and writing the script. Junaidi Indrawadi, collecting and analyzing data; Cici Nur Azizah, and Roni Priyoga Putra collecting data.

\section{ACKNOWLEDGMENT}

This study was financed with funds non-tax revenues, Universitas Negeri Padang with contract number: 3445/UN35.13/TU/2020

\section{REFERENCES}

[1] F. Eriyanti, “'Malakok': Multicultural Concepts Based On Local Wisdom In Minangkabau Community," Integr. Interconnect. Sci. "The Reflect. Islam Kaffah,” no. October, hal. 15-16, 2016.

[2] F. U. Leni Syafyahya, Efri Yades, "Malakoksebagai Dasar Integrasi Oleh Etnis Minangkabau Di Kabupaten Dharmasraya Provinsi Sumatera Barat," vol. 13, hal. 129-140, 2016.

[3] M. M. Randi Adesaputra, Susi Fitria, "INTEGRASI SOSIAL BERBASIS KEARIFAN LOKAL MALAKOK TERHADAP ETNIS PENDATANG DI PASAR USANG SUMATERA BARAT," J. Pendidik. Tambusai, vol. 3, no. 2, hal. 894-901, 2019.

[4] H. Thamrin, "Revitalisasi Kearifan Lokal Melayu Dalam Menjaga Harmonisasi Lingkungan Hidup," 
Toler. Media Komun. Umat Bergama, vol. 6, no. 1, hal. 90-106, 2014.

[5] M. Kamal, "Harmoni in Diversity: Study on Potential Harmonious Multicultural Society 'Pantara' Regions Notrhern Border of West Sumatera," Islam. Realitas J. Islam. Soc. Stuidies, vol. 4, no. 1, hal. 57, 2018.

[6] Sefriyono, "Malakok: Model Menegosiasikan Keragaman bagi Etnis Nias-Kristen dan Minangkabau-Islam di Kabupaten Padang Pariaman," Penelit. Pengabdi., vol. 3, no. 2, hal. 200-212, 2015.

[7] I. (b) Moeis, "POTENSI MULTIKULTURAL DALARI SOSIO BUDAYA MINANGKABAU: Ditinjau dari Perspektif Kritis," in Peran Ilmu-Ilmu Sosial dalam Pembangunan Indonesia Baru, 2014, hal. 532.

[8] Hafizah, "Malakok sebagai Syarat Untuk Menjadi Warga Masyarakat di Nagari Tanjung Sani Kabupaten Agam," J. Kepemimp. san Kepengurusan Sekol., vol. 2, no. 2, hal. 149-158, 2017.

[9] E. Nurhayati dan Y. Nurhidayah, "Multicultural Value in the Traditional Islamic Boarding School, Bina Insan Mulia (BIMA), Cirebon, Indonesia," Nadwa, vol. 1, no. 1, hal. 185, Agu 2019.

[10] I. Moeis, Pendidikan Multikultural transfromatif. Padang: Universitas Negeri Padang, 2014.

[11] Chinaka Samuel DomNakwachukuwu, An Introduction to Multicultural Education. Lanham • New York • Toronto • Plymouth, UK: ROWMAN \& LITTLEFIELD PUBLISHERS, INC, 2010.

[12] J. A. Banks, An introduction to multicultural education. ERIC, 1994.

[13] Y. Z. Ansori, I. A. Budiman, dan D. S. Nahdi, "Fostering Diversity Attitudes Through the Internalization of Multicultural Values," in 3rd International Conference on Learning Innovation and Quality Education (ICLIQE 2019), 2020, vol. 397, no. Icliqe 2019, hal. 1348-1352.

[14] Biyanto, "Berdamai dengan Pluralitas Paham Keberagaman," J. Tasawuf dan Pemikir. Islam, vol. 5, no. 1, hal. 164-189, 2015.

[15] S. Gündemir, A. C. Homan, A. Usova, dan A. D.
Galinsky, "Multicultural meritocracy: The synergistic benefits of valuing diversity and merit," J. Exp. Soc. Psychol., vol. 73, no. 446, hal. 34-41, 2017.

[16] P. Çelik, M. Storme, dan B. Forthmann, "A new perspective on the link between multiculturalism and creativity: The relationship between core value diversity and divergent thinking," Learn. Individ. Differ., vol. 52, hal. 188-196, 2016.

[17] L. Sandercock, "Negotiating fear and desire: The future of planning in multicultural societies," Urban Forum, vol. 11, no. 2, hal. 201-210, 2000.

[18] J. W. Berry, "Integration and Multiculturalism : Ways towards Social Solidarity," Pap. Soc. Represent., vol. 20, hal. 2.1-2.21, 2011.

[19] Z. Aziz, A. Salleh, dan H. E. Ribu, "A study of national integration: Impact of multicultural values," Procedia - Soc. Behav. Sci., vol. 7, no. 2, hal. 691-700, 2010.

[20] O. Hovdelien, "Education and Common Values in a Multicultural Society - The Norwegian Case," $J$. Intercult. Stud., vol. 36, no. 3, hal. 306-319, 2015.

[21] I. Indraddin, P. Rahayu, dan S. Nurhaliza, "Local Wisdom For Social Integration In Multiethnic Nagaris," in Iconshel 2018 spetember 5-6, 2019.

[22] I. Moeis, "Potensi Multikultural dalam Sosio Budaya Minangkabau," in Peran Ilmu Sosial dalam pembangunan Indonesia baru 15-17 oktober 2014, 2014, hal. 532-540.

[23] J. W. Creswell dan J. D. Creswell, Research Design:Qualitiative, Quantitative, and Mixed Methods Approches. 2018.

[24] I. Moeis, "Multiculturalism in Liberal and Islamic Perspectives: A Philosophical Review," Int. J. Educ. Stud., vol. 2, no. 1, hal. 17-24, 2009.

[25] I. (a) Moeis, Pendidikan Multikultural Transformatif: Integritas Moral, Dialogis dan Adil. Padang: Universitas Negeri Padang (UNP) Press, 2014.

[26] Wiyanto, "IMPLEMENTASI NILAINILAIMULTIKULTURAL PADA SEKOLAHMULTI-ETNIK," Journal of Ecodunamika, vol. 53, no. 9. hal. 1689-1699, 2012. 
[27] S. Sapendi, "Internalisasi Nilai-nilai Multikultural dalam Pembelajaran Pendidikan Agama Islam di Sekolah (Pendidikan Tanpa Kekerasan)," Raheema, vol. 2, no. 1, hal. 91-113, 2015.

[28] W. A. Lestariningsih, J. Jayusman, dan A. Purnomo, "Penanaman Nilai-Nilai Multikultural dalam Pembelajaran Sejarah di SMA Negeri 1 Rembang Tahun Pelajaran 2017/2018," Indones. J. Hist. Educ., vol. 6, no. 2, hal. 123-131, 2018.

[29] K. Khotimah dan J. Januarizal, "Pendidikan Islam Berbasis Multikultural," Toler. Media Ilm. Komun. Umat Beragama, vol. 9, no. 2, hal. 114, 2017.

[30] Y. Nova, "Dampak Transmigrasi Terhadap Kehidupan Sosial Masyarakat: Studi Sejarah Masyarakat Timpeh Dharmasraya," J. Ilmu Sos. Mamangan, vol. 5, no. 1, hal. 23, 2016.

[31] U. Lionar dan A. Mulyana, "Nilai-Nilai Multikultural Dalam Pembelajaran Sejarah: Identifikasi Pada Silabus," IJSSE Indones. J. Soc. Sci. Educ., vol. 1, no. 1, hal. 11-25, 2019.

[32] P. Suparlan, "Menuju Masyarakat Indonesia yang Multikultural," Antropol. Indones., vol. 0, no. 69, hal. 16-19, 2014.

[33] M. Egerer, C. Ordóñez, B. B. Lin, dan D. Kendal, "Multicultural gardeners and park users benefit from and attach diverse values to urban nature spaces," Urban For. Urban Green., vol. 46, no. August, hal. 126445, 2019.

[34] L. Blum, "Three educational values for a multicultural society: Difference recognition, national cohesion and equality," J. Moral Educ., vol. 43, no. 3, hal. 332-344, 2014.

[35] M. E. Castaneda dan J. Bateh, "Strategies for multicultural managment," J. Int. Educ. Res., vol. 9, no. 1, hal. 41-46, 2013. 